\title{
Factors Associated with Herbs Clinic Utilization in Patients with Diabetes Mellitus in Tawangmangu, Central Java
}

\author{
Agus Triyono,,2), Bhisma Murti'), Hanung Prasetya2) \\ 1)Masters Program in Public Health, Universitas Sebelas Maret \\ ${ }^{2)}$ School of Health Polytechnics Surakarta
}

\section{ABSTRACT}

Background: The utilization of herbs increased for complementary medicine and alternative chronic diseases including Diabetes Mellitus (DM). There are many factors that affect patients with Diabetes Mellitus to utilize herbal clinic. This study aimed to analyze the effects of age, gender, education, occupation, income, marital status, family support, knowledge of herbs, attitude towards herbs, and duration of Diabetes Mellitus on herbs clinic utilization.

Subjects and Method: This was a cross-sectional study. This study was conducted in Tawangmangu, Central Java, from January to March 2020. A sample of 200 DM patients aged 15-60 years who were examined at Jamu Research House (RRJ) or community health center in Tawangmangu. The sample was collected by purposive sampling. The dependent variable was herbs clinic utilization. The independent variables were sex, age, education, occupation, income, marital status, family support, knowledge of herbs, attitude towards herbs, and duration of DM. The data were collected by questionnaire and analyzed by path analysis run on Stata 13.

Results: Herbs clinic utilization was directly increased by positive attitude towards herbs $(\mathrm{OR}=5.37 ; 95 \% \mathrm{CI}=2.49$ to $11.60 ; \mathrm{p}<0.001)$, duration of $\mathrm{DM} \geq 5$ years $(\mathrm{OR}=2.02 ; 95 \% \mathrm{CI}=$ 1.00 to $4.07 ; \mathrm{p}=0.040$ ), high family income $(\mathrm{OR}=2.67 ; 95 \% \mathrm{CI}=1.41$ to $5.01 ; \mathrm{p}=0.003)$, good family support $(\mathrm{OR}=1.93 ; 95 \% \mathrm{CI}=0.96$ to $3.87 ; \mathrm{p}=0.063)$, age $\geq 35$ years $(\mathrm{OR}=1.45$; $95 \% \mathrm{CI}=0.27$ to $7.19 ; \mathrm{p}=0.666)$, female (OR= $0.59 ; 95 \% \mathrm{CI}=0.31$ to $1.12 ; \mathrm{p}=0.108$ ), and married $(\mathrm{OR}=0.64 ; 95 \% \mathrm{CI}=0.26$ to $1.61 ; \mathrm{p}=$ 0.343). Herb clinic utilization was indirectly affected by knowledge of herbs, education, and occupation.

Conclusion: Herbs clinic utilization is directly increased by positive attitude towards herbs, duration of $\mathrm{DM} \geq 5$ years, high family income, good family support, age $\geq 35$ years, female, and married. Herb clinic utilization is indirectly affected by knowledge of herbs, education, and occupation.

Keywords: herbs clinic utilization, Diabetes Mellitus, path analysis

\section{Correspondence:}

Agus Triyono. Masters Program in Public Health, Universitas Sebelas Maret, Jl. Ir. Sutami No 36 A, Surakarta 57126, Central Java, Indonesia. Email: agustriyono_21@yahoo.com. Mobile: +6281329038465 .

Cite this as:

Triyono A, Murti B, Prasetya H (2020). Factors Associated with Herbs Clinic Utilization in Patients with Diabetes Mellitus in Tawangmangu, Central Java. J Health Promote Behav. 05(03): 147-156. https://doi.org/10.26911/thejhpb.2020.05.03.01.

cc) (†) (-) Journal of Health Promotion and Behavioris licensed under a Creative Commons EY NC SA Attribution-NonCommercial-ShareAlike 4.0 International License.

\section{BACKGROUND}

Diabetes mellitus (DM) is a metabolic disease characterized by hyperglycemia. It occurs due to impaired insulin secretion, insulin action, or both. The classic symptoms of DM are polyuria, polydipsia, and polyphagia followed by blood sugar levels of $\geq 200 \mathrm{mg} / \mathrm{dl}$ and or fasting blood sugar of $\geq 126 \mathrm{mg} / \mathrm{dl}$ (ADA, 2017). The risks of DM are positively related to a ffamily history of DM, diet, low physical activity, central obesity, stress, history of hypertension, and 
smoking habits (Ari et al., 2020). DM is ranked third of non-communicable diseases that become a global public health priority (Budiarti et al, 2018).

In 2017, the number of DM sufferers aged 20-79 years in the world was 425 million. In 2045, it is estimated to increase to 629 million (Guariguata et al., 2014). Based on the result of Basic Health Research in 2018, the DM prevalence increased, from $6.9 \%$ in 2015 to $8.5 \%$ in 2018 (Ministry of Health, 2018). In 2018, there were 444,507 new cases of DM in community health centers and hospitals in Central Java. It ranked second highest non-communicable disease. The new cases of DM in community health centers and hospitals in Karanganyar Regency were 3.225 cases. It ranked second highest after hypertension (Dinkes Central Java, 2018).

The DM treatment with chemical drugs causes adverse side effects, such as weight gain, edema, hypoglycemia, lactic acidosis, toxic to the liver, digestive system disorders, and insulin resistance (Zhu and Zhang, 2016). Nowadays, herbs are widely consumed by people for the treatment of chronic diseases including DM (Dewoto, 2007). Based on the data from Basic Health Research in 2010, the Indonesian population who had consumed herbs were $59.12 \%$ and $95.6 \%$ of them received the benefits of consuming herbs (Ministry of Health, 2010).

The number of patient visits to the herbal clinic of the Herbal Medicine Research House (RRJ) of Tawangmangu increased. The average number of patients was 1,100 patients per month in 2012. It became 1,870 patients in 2015 and 2,641 patients in 2017. The number of the visits of patients with DM was ranked third largest in Tawangmangu RRJ herbs clinic. There were several factors affected patients with DM to utilize RRJ herb clinics, such as demographic factors, knowledge about herbs, attitude towards herbs, and the characteristics of DM as a chronic disease. This study aimed to identify the factors that affected patients with DM to utilize RRJ Tawangmangu herbs clinic.

\section{SUBJECTS AND METHOD}

\section{Study Design}

This was an analytic observational study with a cross-sectional design. The study was carried out at the Medicinal Plant and Traditional Medicine Research and Development Center and the Community Health Center in Tawangmangu, Central Java.

\section{Population and Sample}

The population of the study was patients with DM. A sample of 200 DM patients was selected by purposive sampling.

\section{Study Variables}

The dependent variable was herbs clinic utilization. The independent variables were sex, age, marital status, education, occupation, knowledge of herbs, family support, duration of DM, attitude towards herbs, and income.

\section{Operational Definition of Variables}

Sex was the sex of the subjects. This study used questionnaire as the measurement instrument. The measurement scale was categorical, coded o for male and 1 for female.

Age was the age of the subjects of the study when being interviewed. This study used questionnaire as the measurement instrument. The measurement scale was continous, but it was transformed into dichotomous, coded o for $<35$ years and 1 for $\geq 35$ years.

Marital status was the status of the subjects consisted of 3 possibilities, namely unmarried, married, and widow/widower. This study used questionnaires as the measurement instrument. The measurement scale was categorical, coded o for unmarried or widowed and 1 for married. 
Education was the last level of education an individual has achieved based on the last diploma she had from elementary school, junior high school, senior high school, or college level (Cahyaningtyas et al., 2019). This study used questionnaires as the measurement instrument. The measurement scale was categorical, coded o for $<$ Senior High School and 1 for $\geq$ Senior High School. Occupation was the permanent/main job as the main source of income for the study subjects. This study used questionnaires as the measurement instrument. The measurement scale was categorical, coded o for unemployed and 1 for employed.

Income was the amount of family income both main and side job in a month in rupiah. The minimum wage of Karanganyar Regency was Rp 1,833,000. This study used questionnaires as the measurement instrument. The measurement scale was continous, but it was transformed into dichotomous, coded o for $<$ Rp1,833,ooo (low) and 1 for $\geq$ Rp 1,833,ooo (high).

Family Support was family support in the form of material and nonmaterial when the study subjects were looking for types of herbal treatments. This study used questionnaires as the measurement instrument. The measurement scale was continous, but it was transformed into dichotomous, coded o for score $<5.98$ and 1 for $\geq 5.98$.

Knowledge of herbs was the understanding of the subjects about the benefits, efficacy, and safety of herbs. This study used questionnaires as the measurement instrument. The measurement scale was continous, but it was transformed into dichotomous, coded o for score $<5.08$ and 1 for score $\geq 5.08$.

Attitude towards herbs was the DM patient attitude about the benefits, efficacy, and safety of herbal use. This study used questionnaires as the measurement instru- ment. The measurement scale was continous, but it was transformed into dichotomous, coded o for score $<6.89$ and 1 for score $\geq 6.89$.

Duration of Diabetes Mellitus was the length of time the subjects suffered from $\mathrm{DM}$, from the time they were first diagnosed until the time of the interview. This study used questionnaires as the measurement instrument. The data scale was continuous data converted into dichotomous data. $\mathrm{o}$ for $<5$ years and 1 for $\geq 5$ years.

\section{Data Analysis}

This study used univariate, bivariate, and multivariate analysis. Univariate analysis was used to describe the dependent and independent variables. The bivariate analysis was used to determine the correlation between sex, age, marital status, education, occupation, knowledge about herbs, family support, duration of DM, attitude toward herbs, and income towards herbs clinic utilization measured by the Chi-Square test. The multivariate analysis was conducted using the path analysis model with Stata 13 .

\section{Research Ethics}

The ethical clearance in this study was obtained from the Health Research Ethics Committee of Dr. Moewardi Hospital, Surakarta, Indonesia, No:138/I/HREC/2020, January $24^{\text {th }}, 2020$.

\section{RESULTS}

\section{Sample Characteristics}

Table 1 shows the sample characteristics (categorical data). Table 1 shows the majority of the study subjects aged $\geq 35$ years (96.5\%), female (57.5\%), married (85.5\%), low education (73\%), employed (80.5\%), low knowledge of herbs (53\%), supportive towards herbs (73\%), had strong family support (69.5\%), duration of DM was $<5$ years (67\%), and low family income (54\%). 
Triyono et al./ Factors Associated with Herbs Clinic Utilization

Table 1 The characteristics of the subjects of the study

\begin{tabular}{|c|c|c|}
\hline Variable & $\mathbf{n}$ & $\%$ \\
\hline \multicolumn{3}{|l|}{ Sex } \\
\hline Male & 85 & 42.5 \\
\hline Female & 115 & 57.5 \\
\hline \multicolumn{3}{|l|}{ Age } \\
\hline$<35$ years & 7 & 3.5 \\
\hline$\geq 35$ years & 193 & 96.5 \\
\hline \multicolumn{3}{|l|}{ Marital status } \\
\hline Unmarried & 29 & 14.5 \\
\hline Married & 171 & 85.5 \\
\hline \multicolumn{3}{|l|}{ Education } \\
\hline$<$ Senior High School) & 146 & 73.0 \\
\hline$\geq$ Senior High School) & 54 & 27.0 \\
\hline \multicolumn{3}{|l|}{ Occupation } \\
\hline Unemployed & 39 & 19.5 \\
\hline Employed & 161 & 80.5 \\
\hline \multicolumn{3}{|l|}{ Knowledge of herbs } \\
\hline Low & 116 & 53.0 \\
\hline High & 84 & 47.0 \\
\hline \multicolumn{3}{|c|}{ Attitude towards herbs } \\
\hline Supportive & 54 & 27.0 \\
\hline Unsupportive & 146 & 73.0 \\
\hline \multicolumn{3}{|l|}{ Family Support } \\
\hline Weak & 61 & 30.5 \\
\hline Strong & 139 & 69.5 \\
\hline \multicolumn{3}{|c|}{ Duration of Diabetes Mellitus } \\
\hline$<5$ years & 134 & 67.0 \\
\hline$\geq 5$ years & 66 & 33.0 \\
\hline \multicolumn{3}{|l|}{ Family income } \\
\hline Low $(<\mathrm{Rp} 1,833,000)$ & 108 & 54.0 \\
\hline High $(\geq \operatorname{Rp} 1,833,000)$ & 92 & 46 \\
\hline
\end{tabular}

\section{Bivariate Analysis}

The bivariate analysis explained the effect of an independent variable on the dependent variable. The analysis used was the Chi-Square test.

Table 2 shows that high knowledge of herbs $(\mathrm{OR}=2.51 ; 95 \% \mathrm{CI}=1.41$ to $4.47 ; \mathrm{p}=$ $0.003)$, strong family support $(\mathrm{OR}=2.27$; 95\% CI $=1.22$ to $4.22 ; \mathrm{p}=0.014)$, length of illness $\geq 5$ years $(\mathrm{OR}=2.29 ; 95 \% \mathrm{CI}=1.25$ to 4.20; $\mathrm{p}=0.011)$, positive attitude towards herbs $(\mathrm{OR}=5.31 ; 95 \% \mathrm{CI}=2.58$ to $10.93 ; \mathrm{p}$ $<0.001)$, high income $(\mathrm{OR}=2.63$; $95 \% \mathrm{CI}=$
1.48 to $4.68 ; \mathrm{p}=0.001$ ), high education $(\mathrm{OR}=1.11 ; 95 \% \mathrm{CI}=0.593$ to 2,$067 ; \mathrm{p}=$ $0.873)$, age $\geq 35$ years $(\mathrm{OR}=1.35 ; 95 \% \mathrm{CI}=$ 0.294 to $6.18 ; \mathrm{p}=1.000)$, and employed $(\mathrm{OR}=1.57 ; 95 \% \mathrm{CI}=0.772$ to $3.19 ; \mathrm{p}=$ o.284) increased the likelihood of herb clinic utilization.

Table 2 shows that female $(\mathrm{OR}=0.59$; 95\% $\mathrm{CI}=0.33$ to $1.04 ; \mathrm{p}=0.086$ ), and married $(\mathrm{OR}=0.67 ; 95 \% \mathrm{CI}=0.30$ to 1.48 ; $\mathrm{p}=0.422$ ) decreased the likelihood of herbs clinic utilization. 
Triyono et al./ Factors Associated with Herbs Clinic Utilization

Table 2. The results of the bivariate analysis of the effects of the factors associated with herbs clinic utilization in Tawangmangu

\begin{tabular}{|c|c|c|c|c|c|c|}
\hline \multirow{3}{*}{ Independent Variable } & \multicolumn{4}{|c|}{ Checkup Place } & \multirow{3}{*}{$\mathbf{O R}$} & \multirow{3}{*}{$\mathbf{p}$} \\
\hline & \multicolumn{2}{|c|}{ RRJ } & \multicolumn{2}{|c|}{$\begin{array}{l}\text { Community } \\
\text { Health Center }\end{array}$} & & \\
\hline & $\mathbf{n}$ & $\%$ & $\mathbf{n}$ & $\%$ & & \\
\hline \multicolumn{7}{|l|}{ Sex } \\
\hline Male & 49 & 57.6 & 36 & 42.4 & \multirow[t]{3}{*}{0.59} & \multirow[t]{3}{*}{0.086} \\
\hline Female & 51 & $44 \cdot 3$ & 64 & $55 \cdot 7$ & & \\
\hline \multicolumn{5}{|l|}{ Age } & & \\
\hline$<35$ years & 3 & 57.1 & 4 & 42.9 & \multirow[t]{3}{*}{1.35} & \multirow[t]{3}{*}{1.000} \\
\hline$\geq 35$ years & 97 & 50.3 & 96 & 49.7 & & \\
\hline \multicolumn{5}{|l|}{ Marital Status } & & \\
\hline Unmarried & 17 & 58.6 & 12 & 41.4 & \multirow[t]{2}{*}{0.67} & \multirow[t]{2}{*}{0.422} \\
\hline Married & 83 & 48.5 & 88 & 51.5 & & \\
\hline \multicolumn{7}{|l|}{ Education } \\
\hline Low ( $<$ Senior High School) & 72 & 49.3 & 74 & 50.7 & \multirow[t]{2}{*}{1.11} & \multirow[t]{2}{*}{0.873} \\
\hline High ( $\geq$ Senior High School) & 28 & 51.9 & 26 & 48.1 & & \\
\hline \multicolumn{7}{|l|}{ Occupation Status } \\
\hline Unemployed & 16 & 41 & 23 & 59 & \multirow[t]{2}{*}{1.57} & \multirow[t]{2}{*}{0.284} \\
\hline Employed & 84 & 52.2 & 77 & 47.8 & & \\
\hline \multicolumn{7}{|l|}{ Knowledge of Herbs } \\
\hline Low & 47 & 40.5 & 69 & 59.5 & \multirow[t]{3}{*}{2.51} & \multirow[t]{2}{*}{0.003} \\
\hline High & 53 & 63.1 & 31 & 36.9 & & \\
\hline \multicolumn{6}{|l|}{ Attitude towards Herbs } & \\
\hline Negative & 12 & 22.2 & 42 & 77.8 & \multirow[t]{3}{*}{$5 \cdot 31$} & \multirow[t]{2}{*}{$<0.001$} \\
\hline Positive & 88 & 60.3 & 58 & 39.7 & & \\
\hline \multicolumn{6}{|l|}{ Family Support } & \\
\hline Low & 22 & 36.1 & 39 & 63.9 & \multirow[t]{2}{*}{2.27} & 0.014 \\
\hline High & 78 & 56.1 & 61 & 43.9 & & \\
\hline Duration of Diabetes Melli & & & & & & \\
\hline$<5$ years & 58 & $43 \cdot 3$ & 76 & 56.7 & 2.29 & 0.011 \\
\hline$\geq 5$ years & 42 & 63.6 & 24 & 36.4 & & \\
\hline Family Income & & & & & & \\
\hline$<\operatorname{Rp} 1,883,000$ & 42 & 38.9 & 66 & 61.1 & 2.63 & 0.001 \\
\hline$\geq \operatorname{Rp} 1,883,000$ & 58 & 62.6 & 34 & 37.4 & & \\
\hline
\end{tabular}

\section{Path Analysis}

Path analysis contained a model used to analyze the pattern of relationships among the variables with the aim of the study to determine the direct or indirect effect of each independent variable on the dependent variable (Ayuningrum and Murti, 2019).

Table 3 shows the path analysis of factors that affected the behavior of herbs clinic utilization. The utilization of RRJ herbs clinic directly increased with positive attitude toward herbs $(\mathrm{OR}=5.37$; 95\% CI $=$
2.49 to $11.60 ; \mathrm{p}<0.001)$, high income ( $\mathrm{OR}=$ 2.66; $95 \% \mathrm{CI}=1.41$ to $5.01 ; \mathrm{p}=0.003)$, and duration of $\mathrm{DM} \geq 5$ years $(\mathrm{OR}=2.02 ; 95 \%$ $\mathrm{CI}=1.00$ to $4.07 ; \mathrm{p}=0.040$ ), age of $\geq 35$ years $(\mathrm{OR}=1.45 ; 95 \% \mathrm{CI}=0.27$ to $7.19 ; \mathrm{p}=$ o.666), and strong family support (OR= 1.93; $95 \% \mathrm{CI}=0.96$ to $3.87 ; \mathrm{p}=0.063)$. The utilization of RRJ herbs clinic directly decreased with married $(\mathrm{OR}=0.64 ; 95 \%$ $\mathrm{CI}=0.26$ to $1.61 ; \mathrm{p}=0.343)$ and $\mathrm{sex}$ of female $(\mathrm{OR}=0.59 ; 95 \% \mathrm{CI}=0.31$ to $1.12 ; \mathrm{p}=$ o.108).

Herb clinic utilization was indirectly 
affected by knowledge of herbs, education, and occupation.

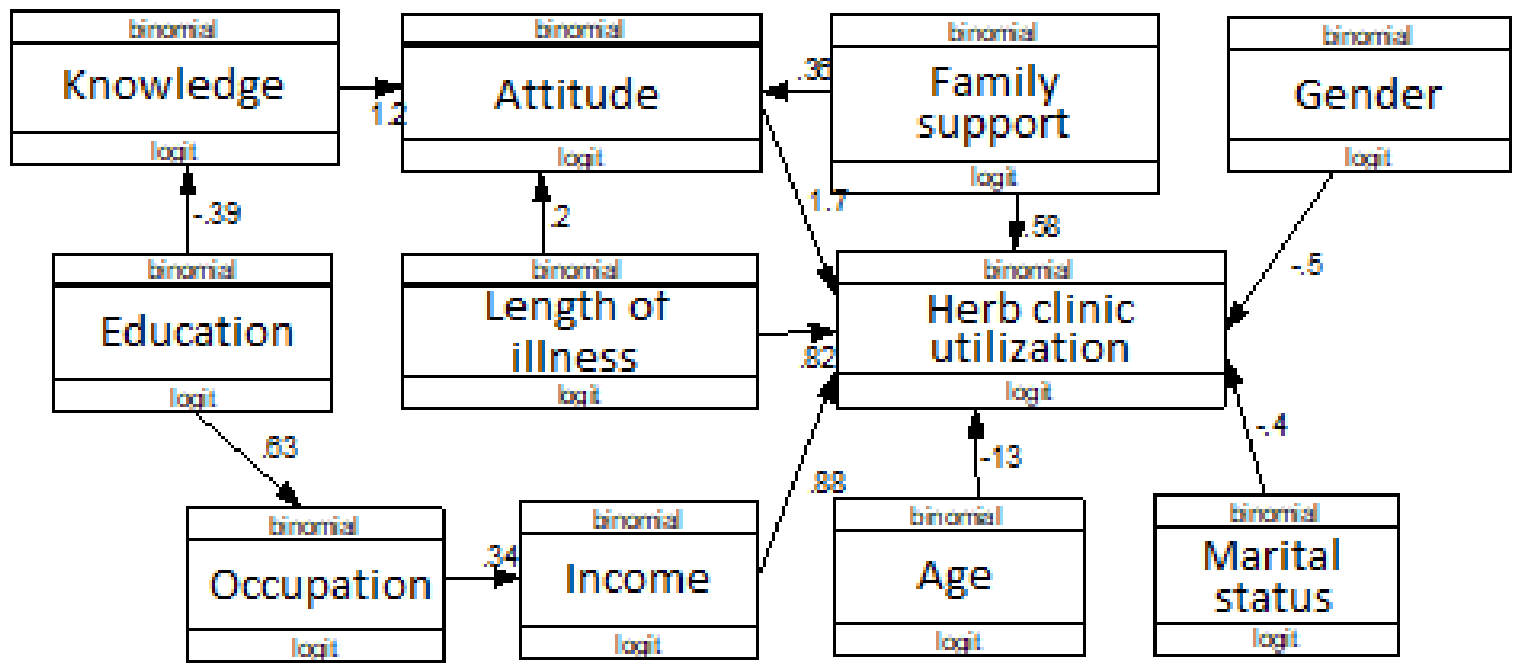

Figure 1. The model of the path analysis of factors affecting herbs clinic utilization in patients with diabetes mellitus towards herbs clinic utilization

Table 3. The result of the path analysis of the effect of independent variables on herbs clinic utilization.

\begin{tabular}{|c|c|c|c|c|c|}
\hline \multirow[b]{2}{*}{ Dependent Variable } & \multirow[b]{2}{*}{ Independent Variable } & \multirow[b]{2}{*}{$\mathbf{O R}$} & \multicolumn{2}{|c|}{ CI (95\%) } & \multirow[b]{2}{*}{$\mathbf{p}$} \\
\hline & & & $\begin{array}{l}\text { Lower } \\
\text { Limit }\end{array}$ & $\begin{array}{l}\text { Upper } \\
\text { Limit }\end{array}$ & \\
\hline \multicolumn{6}{|l|}{ Direct effect } \\
\hline \multirow{7}{*}{$\begin{array}{l}\text { Herbs clinic utilization } \\
\text { (RRJ) }\end{array}$} & $\leftarrow$ Sex (Female $)$ & 0.59 & 0.31 & 1.12 & 0.108 \\
\hline & $\leftarrow$ Age $(\geq 35$ years $)$ & 1.45 & 0.27 & 7.19 & 0.666 \\
\hline & $\leftarrow$ Marital status (married) & 0.64 & 0.26 & 1.61 & 0.343 \\
\hline & $\begin{array}{l}\leftarrow \text { Attitude towards herbs } \\
\text { (positive) }\end{array}$ & $5 \cdot 37$ & 2.49 & 11.60 & $<0.00$ \\
\hline & $\leftarrow$ Family support (good) & 1.93 & 0.96 & 3.87 & 0.063 \\
\hline & $\leftarrow$ Duration of DM $(\geq 5$ years $)$ & 2.02 & 1.00 & 4.07 & 0.040 \\
\hline & $\leftarrow$ Income (adequate) & 2.66 & 1.41 & 5.01 & 0.003 \\
\hline \multicolumn{6}{|l|}{ Indirect effect } \\
\hline \multirow[t]{3}{*}{ Attitude towards herbs } & $\leftarrow$ Knowledge of herbs (good) & 3.23 & 1.56 & 6.68 & 0.002 \\
\hline & $\leftarrow$ Duration of $\mathrm{DM}(\geq 5$ years $)$ & 1.17 & 0.58 & 2.35 & 0.671 \\
\hline & $\leftarrow$ Family support (strong) & 1.36 & 0.68 & 2.70 & 0.384 \\
\hline Knowledge of herbs & $\leftarrow$ Education (high) & 0.68 & 0.35 & 1.29 & 0.236 \\
\hline Occupation & $\leftarrow$ Education (high) & 0.86 & 0.78 & 4.57 & 0.161 \\
\hline Income & $\leftarrow$ Occupation (employed) & 1.47 & 0.71 & 3.00 & 0.294 \\
\hline $\begin{array}{l}\mathrm{N} \text { observation }=200 \\
\mathrm{p}=0.050 \\
\text { Log likelihood }=-587.7\end{array}$ & & & & & \\
\hline
\end{tabular}

\section{DISCUSSION}

1. The effect of attitude towards herbs on herbs clinic utilization

Attitude towards herbs had a direct effect on the utilization of RRJ herbs clinic.
Patients with DM who had quite positive attitude on herbs could use RRJ herbs clinic 5.37 times compared to those who had a less positive attitude towards herbs. The result of this study was in line with a 
study conducted by Pahandayani et al. (2014) that there was a significant relationship between attitude towards herbs utilization. It is supported by a study conducted by Desni et al. (2009) that there was a significant relationship between the attitude of the head of the family towards herbs utilization. The more positive of the attitude of patients with DM towards herbs, the more likely the patients with DM to utilize the herbs clinic. Patients with DM who has positive attitude about herbs believed that herbs were efficacious to help in lowering blood sugar levels and reducing/ preventing the DM disease complications. Patients with DM also believed that herbs were safe for consumption as a DM treatment.

The utilization of herbs for the DM treatment could be used with chemical drugs (as complementary) for patients with DM with high blood sugar levels. It could be used for self-utilization without any chemical drugs (alternative) for patients with DM with moderate blood sugar levels. The attitude of the patients that was quite postive towards herbs also appeared because the RRJ herbs clinic as the Technical Implementation Unit of the Agency of Health Research and Development of the Ministry of Health. RRJ herbs clinic services were carried out by the educated health workers namely doctors, nurses, pharmacists, D3 Pharmacy, and health analysts. RRJ Clinic had also passed the ISO service standard. A positive attitude on herbs would increase self-efficacy (the ability to be experienced by the patients with DM in carrying out the desired behavior) namely the herbs clinic utilization (Aprillia, 2019).

\section{The effect of income on herbs clinic utilization}

Income directly affected the utilization of RRJ herbs clinic. Patients with DM, with adequate income, could utilize RRJ herbs clinic 2.66 times compared to less income. This study was is in line with a study conducted by Ismail (2015) that there was an effect of income on herbs clinic utilization. According to Budiarti et al. (2018), high income was positively correlated with herbal utilization. The majority of herbs clinic users (59.6\%) has quite high income. According to Ahmed and Bukhari (2011), adequate income had a quite positive correlation on the herbs utilization. The result was significant. Based on the result of the review of the 50 articles by Bishop and Lewith (2010), 41 articles explained that adequate income increased the selection of herbs utilization. Besides, 9 articles explained that adequate income reduced the herbs utilization.

An adequate income allowed the patients with DM to access RRJ herbal clinic services. The cost of treatment at the RRJ herbs clinic was as follows: the registration fee was Rp5,00o and the herbs cost for each use was Rp30,00o each week. Besides, the treatment cost at the community health center was Rp5,00o for the registration fees and medicine costs.

\section{The effect of duration of Diabetes} Mellitus on herbs clinic utilization

The duration of DM had a direct effect on the herbs clinic utilization by the patients with DM. Patients with DM with the duration of $\geq 5$ years had a risk to utilize the RRJ herbs clinic 2.02 times compared to a duration of $<5$ years. According to Zhang et al. (2016) and Hamzah (2019), long-term treatment of DM with chemical drugs had side effects quite often. Therefore, the patients who have suffered from DM for a long time often got bored consuming chemical drugs, thus utilizing the herbs.

The patients who have been suffering from DM for a long time had macrovascular complications (coronary heart disease, peripheral arterial disease, and stroke) and/or 
microvascular complications (neuropathy, retinopathy, and nephropathy). The complications affected DM patients to look for alternative complementary medicine, including RRJ herbal clinic utilization. Efforts in controlling Diabetes aimed to prevent microvascular and macrovascular complications (Prasetyowati et al., 2018).

\section{The effect of marital status on herbs clinic utilization}

Marital status directly affected the herbs clinic utilization in patients with DM. Patients with DM who got married could utilize RRJ herbs clinic 0.64 times compared to those who did not get married. The result of this study is in line with a study conducted by Rambod et al. (2018) that patients who got married could utilize herbs clinic 0.35 times compared to those who did not get married. The result of this study was not in accordance with a study conducted by Dini and Mufdlilah (2012) that the dominant factor affecting patients utilizing herbal clinic was marital status.

\section{The effect of family support on herbs clinic utilization}

Family support had a direct effect on the herbs clinic utilization of patients with DM. Patients with DM, with good family support, were more likely to utilize RRJ herbal clinic 1.93 times compared to those who had poor family support. This study is in line with a study conducted by Pahandayani et al. (2014) that there was a significant relationship between family support and herbal utilization.

The forms of family support in utilizing the herbal clinic in patients with DM were by providing information about herbal clinic services, suggesting treatment at an herbal clinic, helping to fund a treatment at an herbal clinic or accompanying for a treatment to an herbal clinic.

\section{The effect of sex on herbs clinic utilization}

Sex directly affected the herbs clinic utilization in patients with DM. Female patients with DM had the risk to utilize RRJ herbal clinic 0.59 times compared to male patients. The result of this study is in line with a study conducted by Hasan et al. (2011) that the majority of herbal clinic users were male (52.6\%). However, The result of this study was not in line with a study conducted by Sawalha et al. (2010) that female patients might utilize herbs 1.2 times compared to male patients. Based on the result of the review of the 64 articles by Bishop and Lewith (2010), there were 64 articles, including 63 articles explaining that women preferred herbs utilization. Another 1 article explained that men preferred herbs utilization. Based on a study conducted by Wazaify et al. (2011), 59.6\% of herbal users were female.

\section{The effect of age on herbs clinic utilization}

Age had a direct effect on the herbs clinic utilization in patients with DM. The patients with DM aged $\geq 35$ years could utilize RRJ herbal clinic 1.45 times compared to those aged $<35$ years old. The result of this study is in line with a study conducted by Supardi and Susyanty (2010) that the elderly group preferred herbs treatment 1.66 times than the young group. It might occur because at the age of $\geq 35$ years, they preferred herbs treatment or wanted to use herbs as an alternative complementary treatment. Based on a study conducted by Mulyani (2011), older age was very influential on the selection of herbs. Based on a study conducted by Wazaify et al. (2011), 1,000 diabetic patients were interviewed. A total of $16.6 \% \quad(n=166)$ of them utilized herbs. A total of $91.6 \%(n=152)$ of herbal users were in the age group of $\geq 40$ years. 
AUTHOR CONTRIBUTION

Agus Triyono conducted the study, collected the data and wrote the articles. Hanung Prasetya formulated the study background and discussion. Bhisma Murti formulated the the theoretical framework and analyzed the data.

\section{CONFLICT OF INTEREST}

This study did not have any conflict of interest.

\section{FUNDING AND SPONSORSHIP}

This study used a personal fund.

\section{ACKNOWLEDGEMIENT}

We give the best gratitude to the Head of the Medicinal Plant and Traditional Medicine Research and Development Center and the Head of the Community Health Center in Tawangmangu who allowed us to conduct this study. We also give gratitude to all of the patients with Diabetes Mellitus who have been willing and cooperative to become the respondents of the study.

\section{REFERENCE}

Ahmed SI, Bukhari NI (2011). Reasons, perceived efficacy and faktors associated with complementary and alternatif medicine use among Malaysian patients with diabetes mellitus. Br J Diabetes Vasc Dis. 11(2): 92-98. https://doi.org/10- .1089/ acm.2009.0657

American Diabetes Association (2017). Classification and diagnosis of diabetes. Diabetes care. 40(1): S11-S24. https://doi.-org/10.2337/dc17-Soo5

American Diabetes Association (2016). Standards of medical care in diabetes-2016: summary of revisions. Diabetes care. 39(1): S4-S5. https://doi.org/10.2337/dc16-Soo3

Aprillia N, Tamtomo D, Sulaeman ES (2019). Path Analysis on the effectiveness of chronic disease prevention program using Health Belief Model. J Health Promot Behav. 4(2): 85-97. https://doi.org/10.26911/thejhpb.201 9.04.02.01.

Ari AP, Qadrijati I, Murti B (2020). Multilevel analysis: Villages do not have ecological effect on the risk of diabetes mellitus type 2 in Surakarta, Central Java. J Epidemiol Public Health. 05(01): 106-118. https://doi.org/10.26911/jepublichealth.2020.05.01.11.

Ayuningrum IY, Murti B (2019). Aplikasi path analysis dan structural equation model dengan stata. Program Studi Ilmu Kesehatan Masyarakat, Program Pasca Sarjana UNS. Surakarta

Bishop FL, Lewith GT (2010). Who uses CAM? A narrative review of demographic characteristics and health faktors associated with CAM use. Evid Based Complement Alternat Med. 7(1): 1128. https://doi.org/10.1093/ecam/neno23.

Budiarti E, Tamtomo DG, Adriani RB (2018). Path analysis on the biopsychosocial determinants of type 2 diabetes mellitus and depression at Dr. Moewardi Hospital, Surakarta. J Epidemiol Public Health. 3(1): 1-14. https://doi.org/10.26911/jepublicheal th.2018.03.01.01\%20

Cahyaningtyas NA, Sudiyanto A, Soemanto RB (2018). Socioeconomic determinants of healthy ageing and the contextual effect of peer group: A multilevel evidence from Blora, Central Java. J Epidemiol Public Health. 4(1): 30-36. https://doi.org/10.26911/jepublichealth. 2019.04 .01 .04

Dewoto HR (2007). Pengembangan obat tradisional Indonesia menjadi fitofarmaka. MKI. 57(7): 205-211.

Dini A, Mufdlilah M (2012). Faktor-faktor yang mempengaruhi pasien melakukan pengobatan tradisional ke balai 
pengobatan tradisional di Yogyakarta Tahun 2012 (Doctoral dissertation, STIKES' Aisyiyah Yogyakarta). Retrieved from http://digilib.unisayogya.ac.id/id/eprint/1462.

Guariguata L, Whiting DR, Hambleton I, Beagley J, Linnenkamp U, Shaw JE (2014). Global estimates of diabetes prevalence for 2013 and projections for 2035. Diabetes Res Clin Pract. 103(2): 137-149. https://doi.org/10.1016/j.diabres.2013.11.002.

Hamzah DF (2019). Analisis penggunaan obat herbal pasien diabetes mellitus tipe 2 di kota langsa. Jumantik. 4(2): 168-177. http://dx.doi.org/10.30829/jumantik.v4i2.5057.

Hasan SS, Loon WC, Ahmadi K, Ahmed SI, Bukhari NI (2011). Reasons, perceived efficacy and faktors associated with complementary and alternatif medicine use among Malaysian patients with diabetes mellitus. Br J Diabetes Vasc Dis. 11(2): 92-98. https://doi.org/10.1177\%2F1474651410398367.

Kementerian Kesehatan (2018). Riset kesehatan dasar tahun 2018. Jakarta: Kemenkes RI. Retrieved from https://www.litbang.kemkes.go.id/laporanriset-kesehatan-dasar-riskesdas/

Mulyani DS (2011) Studi pemahaman dan alasan pemilihan obat herbal pada pasien poliklinik penyakit dalam RSUP dr. sardjito yogyakarta. Yogyakarta.

Murti B (2018). Prinsip dan metode riset epidemiologi. Program Studi Ilmu Kesehatan Masyarakat. Program Pasca Sarjana UNS. Surakarta

Pahandayani P (2014). Factors associated option alternatif herbal treatment of diabetes mellitus patients at home research herbal Hortus Medicus Tawangmangu. Skripsi. Program Studi Kesehatan Masyarakat. Ilmu Kese- hatan Masyarakat Universitas $\mathrm{Mu}-$ hammadiyah Surakarta.

Prasetyowati U, Tamtoto D, Murti B (2018). Path analysis: Factors associated with self preventive care among patients with type 2 diabetes mellitus in Surakarta. J Health Promot Behav. 3(2): 86-93. https://doi.org/10.26911/thejhpb. 2018.03.02.01

Rambod M, Nazarinia M, Raieskarimian F (2018). The prevalence and predictors of herbal medicines usage among adult rheumatoid arthritis patients: A case-control study. Complement Ther Med. 41: 220-224. https://doi.org/10$.1016 /$ j.ctim.2018.10.004

Sawalha AF, Sweileh WM, Sa'ed HZ, Jabi SW (2010). Self-therapy practices among university students in Palestine: focus on herbal remedies. Complement Ther ed. 16(6): 343-349. https://doi.org/10.1016/j.ctim.2007.1 2.002

Supardi S, Susyanty AL (2010). Penggunaan Obat Tradisional dalam upaya pengobatan sendiri di Indonesia (Analisis data susenas tahun 2007). Buletin Penelitian Kesehatan, 38 (2):89-89. Retrieved from https://media.neliti.com/media/publications /20173-ID-penggunaan-obat-tradisional-dalam-upaya-pengobatan-sendiri-di-indonesia-analisis.pdf.

Wazaify M, Afifi FU, El-Khateeb M, Ajlouni $\mathrm{K}$ (2011). Complementary and alternatif medicine use among Jordanian patients with diabetes. Complement Ther Clin Pract. 17(2): 71-75. https://doi.org/10.1016/j.ctcp.2011.02.002

Zhang C, Rawal S, Chong YS (2016). Risk faktors for gestational diabetes: is prevention possible?. Diabetologia. 59(7): 1385-1390. https://doi.org/10.1007/s00125-016-397 